\title{
Analgesia for the critically ill patient
}

\author{
Jamie Riggs, Dominic Wang
}

\section{CLINICAL NARRATIVE}

You are the ICU fellow on call overnight at a tertiary care hospital. At approximately $2 \mathrm{AM}$, you receive a call from the emergency department (ED) with a consult. The ED resident gives you the following details: Mrs P is a 67 year old woman who presented recently with acute dyspnea and severe pain focused around an area of extensive erythema on her left arm. She has a pulse rate of 115 , respiratory rate 45 breaths per minute, temperature $39^{\circ} \mathrm{C}$, blood pressure $95 / 65 \mathrm{~mm} \mathrm{Hg}$, and $\mathrm{O} 2$ saturation $68 \%$ on room air. The resident also notes areas of dark and yellowish tissue surrounding her left elbow, which are suspected to be necrotic. She is currently receiving $100 \% \mathrm{O} 2$ via a high flow mask and fluid resuscitation via two peripheral IVs. She is experiencing severe pain, which she rates as $10 / 10$, but is otherwise stable. You agree to have this patient transferred to your care. While she is on the way up you remind yourself of the key components of pain management in the critically ill patient.

\section{PAIN IN THE CRITICALLY ILL PATIENT}

Pain is defined by the International Association for the Study of Pain as an "unpleasant sensory and emotional experience associated with actual or potential tissue damage, or described in terms of such damage." Pain-related issues are a major cause of presentation to the ED, with estimates as high as $70 \%$ of patients. ${ }^{2} \mathrm{~A}$ majority of patients will experience pain at some point during their stay in an intensive care unit (ICU) and identify pain as a major source of stress. ${ }^{1}$

The complications associated with poorly controlled pain in ICU patients must not be underestimated. Studies have shown that $82 \%$ of cardiac surgery ICU patients report pain as the most traumatic memory of their ICU stay. ${ }^{3}$ Other studies have reported that $18 \%$ of ICU patients are at high risk for developing posttraumatic stress disorder 6 months after their stay due to memories associated with pain. ${ }^{4}$ Poorly controlled pain has deleterious physiologic consequences; additionally, increased catecholamines associated with the stress response can impair tissue perfusion. ${ }^{5}$ Pain has also been shown to suppress critical immune-related processes such as natural killer cell, neutrophil, and T-cell activity. ${ }^{6,7}$ Therefore, appropriate pain management in all ICU patients must be considered an essential aspect of their care.

\section{ASSESSMENT OF PAIN IN THE ICU}

Assessment of the patient's level of pain is a foundational element of treatment. ${ }^{1}$ Numerous pain rating scales exist, such as the ubiquitous 1-10 rating scale often used in the ED, as well as in other settings. ${ }^{8}$ Assessing pain in the ICU presents additional challenges, as many patients will be hindered in their ability to self-report. Critically ill patients may have altered levels of consciousness, be mechanically ventilated, or be administered high doses of sedatives. ${ }^{9}$ However, the International Association for the Study of Pain notes that "the inability to communicate verbally does not negate the possibility that an individual is experiencing pain and is in need of pain-relieving treatment". ${ }^{10}$

Objective and reproducible assessment of pain should be the goal in all patients experiencing pain. Patient self-reported pain is considered the gold standard. ${ }^{1}$ In patients who are not able to verbalize their responses, the use of visual scales has been shown to be the next best alternative, ${ }^{11}$ though implementation is limited to patients with a suitable level of consciousness. Numerous scales based on observed patient behaviour have been devised, and their use has been shown to improve clinical outcomes and pain management when used consistently. ${ }^{12}$ Most importantly, the assessment of pain must be carried out consistently throughout a patient's stay in the ICU to ensure the most appropriate management.

\section{TREATING PAIN IN THE ICU}

Analgesic medications may be broadly classified as either opioid or non-opioid medications. Opioid medications (eg fentanyl, hydromorphone, morphine, methadone) are considered firstline medications for pain management in critically ill patients. ${ }^{1}$ Choosing between the numerous opioid medications depends upon patient and medication characteristics. Patient factors include previous exposure to opioids, co-morbidities such as renal or hepatic disease, and hemodynamic stability. The rate of onset and elimination half-life of each medication also varies significantly and are important considerations. These properties are shown for select opioid medications in Table 1.

Non-opioid analgesics may be used as adjuncts in some circumstances. ${ }^{1}$ They may be used to decrease the required dose of opioids, or to decrease opioid-related side effects (refer to Table 1). These have not been well studied in the ICU setting. Other nonpharmacological interventions have been proposed, including music and relaxation therapy. These interventions may reduce the required dose of opioids and are relatively low cost, safe, and easy to provide in appropriate patients. While limited evidence exists to support the effectiveness of these interventions, focus groups conducted with ICU patients and their caregivers have indicated that certain non-pharmacological interventions were found to be useful. ${ }^{13}$

What is the initial strategy with regards to pain management in the ED? What considerations must be taken into account in this case?

You ask the emergency physician whether any analgesia has already been provided and learn that a $0.5 \times \mathrm{g} / \mathrm{kg}$ IV dose of fentanyl was given approximately 15 minutes ago. This is an excellent choice, 
given that fentanyl has a rapid onset and has a relatively long halflife. Although morphine acts similarly, the patient is hypotensive, which could be exacerbated by morphine.

\section{Upon arrival in your unit, what are your first steps in addressing this patient's pain?}

After Mrs P is transferred intoyour care in the ICU, reassessment of her pain should occur promptly. You reassess her pain, and she indicates "a 6 or 7", suggesting that the initial dose of fentanyl has had an effect. At this point, it has been nearly 45 minutes since Mrs P received fentanyl, and so you must decide whether to push another dose or start her on an infusion. Your working diagnosis is necrotizing fasciitis of the elbow, with resulting septic shock. The plastic surgery and infectious disease teams are consulted.

\section{What agent will you choose for ongoing analgesia? What information would you want to make this decision?}

In deciding what agent to choose going forward, you reassess the patient's blood pressure and find that it has increased to $105 / 75$ $\mathrm{mm} \mathrm{Hg}$. She continues to receive fluid through peripheral IVs, and now has a central line inserted for invasive blood pressure monitoring. Considering that Mrs P is now in the more controlled ICU environment, you are comfortable that you will be able to closely monitor and appropriately manage any changes in blood pressure. Mrs P is still able to communicate, and indicates that she used opioids "for a few weeks after a knee operation" several years ago. She does not report any issues with addiction or dependence stemming from this use. At this point you decide to start Mrs P on a morphine infusion at a dose of $5 \mathrm{mg} / \mathrm{h}$.

Mrs. $P$ is treated with IV antibiotics and surgical debridement of her elbow. During the wound debridement, extensive tissue invasion was discovered and a substantial amount of necrotic muscle tissue was removed. She improves markedly with ongoing administration of fluids.

\section{What are the essential steps in the ongoing management of this patient?}

Mrs P must be regularly reassessed throughout her stay in the ICU, and have her morphine infusion titrated to achieve effective analgesia. Given that her management includes a surgical procedure to debride necrotic tissue, special care must be taken in the perioperative and postoperative periods to control her pain.

\section{DISCHARGE AND FOLLOW UP}

As Mrs P's condition improves, preparations for discharge from the ICU are undertaken. Pain management is an essential component of follow-up care, as more than half of ICU patients report ongoing problems with pain many years after their discharge. ${ }^{14}$ Appropriate referral to rehabilitation services and practitioners who can provide ongoing support should be made. In some centres, specialized patient navigators work with each patient and their caregivers to facilitate care in the year following discharge..$^{15}$ It remains to be seen whether these programs will significantly impact patient outcomes.
Patients, caregivers, and practitioners may be concerned that opioids administered in the ICU will lead to dependence on the drugs. A follow up study of 2595 patients admitted to the ICU at a tertiary care hospital found that there was a decrease in opioid use at 48 months post-discharge, with only $1.8 \%$ of patients using opioids on most days, compared to $6.2 \%$ using opioids most days prior to admission. ${ }^{16}$ These findings suggest that post-ICU opioid dependence is rare.

Patients who remain on opioid medications post-discharge for chronic, non-cancer pain must be followed closely by an experienced practitioner. The 2017 Canadian Guideline for Opioids for Chronic Non-Cancer Pain recommends a 5 to $10 \%$ dose reduction rate every 2 to 4 weeks for patients on high doses of morphine (>90 mg daily). ${ }^{17}$ Rotation between opioids as a potential strategy to taper dosage for gradual withdrawal was also suggested. This requires close monitoring, and regular follow-up visits must be scheduled. Each session should discuss functional goals, psychosocial support, and plans for withdrawal symptoms and re-emerging pain.

Table 1. Pharmacology of opioid and non-opioid analgesics

\begin{tabular}{|c|c|c|c|c|c|}
\hline Class & Analgesic & $\begin{array}{c}\text { Route of } \\
\text { Administration }\end{array}$ & Onset & Half-Life & $\begin{array}{l}\text { Contraindications, Side Effects, } \\
\text { and Other Information }\end{array}$ \\
\hline \multirow[t]{5}{*}{ Opioid } & Fentanyl & IV & $1-2 \mathrm{~min}$ & $2-4 \mathrm{~h}$ & $\begin{array}{l}\text { Contraindicated by hepatic } \\
\text { impairment. Induces hypotension, } \\
\text { though less dramatically than } \\
\text { morphine }\end{array}$ \\
\hline & Remifentanil & IV & $1-3 \mathrm{~min}$ & 3-10 min & $\begin{array}{l}\text { Can be used in patients presenting } \\
\text { with hepatic or renal failure }\end{array}$ \\
\hline & Morphine & IV & 5-10 min & 3-4 h & $\begin{array}{l}\text { Contraindicated by hepatic or renal } \\
\text { impairment }\end{array}$ \\
\hline & Hydromorphone & IV & 5-15 min & $2-3 \mathrm{~h}$ & $\begin{array}{l}\text { Contraindicated by hepatic or renal } \\
\text { impairment. Consider usage for } \\
\text { patients with morphine or fentanyl } \\
\text { tolerance }\end{array}$ \\
\hline & Methadone & IV & $1-3 d$ & $15-60 \mathrm{~h}$ & $\begin{array}{l}\text { A potent analgesic itself, but it can } \\
\text { also be used to slow the } \\
\text { development of tolerance to } \\
\text { opioids when there is an escalation } \\
\text { of opioid dosing requirements. } \\
\text { Unpredictable pharmacokinetics; } \\
\text { unpredictable pharmacodynamics } \\
\text { in opiate naïve patients. Monitor } \\
\text { QTc for arrhythmia }\end{array}$ \\
\hline \multirow[t]{8}{*}{$\begin{array}{l}\text { Non- } \\
\text { Opioid }\end{array}$} & Ketamine & IV & $30-40 \mathrm{~s}$ & $2-3 \mathrm{~h}$ & $\begin{array}{l}\text { May cause hallucinations and other } \\
\text { psychological disturbances. } \\
\text { Attenuates the development of } \\
\text { acute tolerance to opioids }\end{array}$ \\
\hline & Acetaminophen & IV & 5-10 min & $2 \mathrm{~h}$ & $\begin{array}{l}\text { May be contraindicated by } \\
\text { significant hepatic dysfunction }\end{array}$ \\
\hline & Ketorolac & $\mathrm{IV} / \mathrm{IM}$ & $10 \mathrm{~min}$ & $2.4-8.6 \mathrm{~h}$ & $\begin{array}{l}\text { Contraindicated by renal } \\
\text { dysfunction, gastrointestinal } \\
\text { bleeding, platelet abnormalities, } \\
\text { concomitant ACE inhibitors, } \\
\text { congestive heart failure, cirrhosis, } \\
\text { and asthma }\end{array}$ \\
\hline & Ibuprofen & IV & N/A & $2.2-2.4 \mathrm{~h}$ & $\begin{array}{l}\text { See contraindications listed for } \\
\text { Ketorolac }\end{array}$ \\
\hline & Ibuprofen & PO & $25 \mathrm{~min}$ & $1.8-2.5 \mathrm{~h}$ & $\begin{array}{l}\text { See contraindications listed for } \\
\text { Ketorolac }\end{array}$ \\
\hline & Acetaminophen & $\mathrm{PO} / \mathrm{PR}$ & $30-60 \mathrm{~min}$ & $2-4 \mathrm{~h}$ & $\begin{array}{l}\text { May be contraindicated by } \\
\text { significant hepatic dysfunction }\end{array}$ \\
\hline & $\begin{array}{l}\text { Carbamazepine } \\
\text { (immediate } \\
\text { release) }\end{array}$ & PO & $4-5 \mathrm{~h}$ & $\begin{array}{c}25-65 \mathrm{~h} \text { initially, } \\
12-17 \mathrm{~h} \\
\text { subsequently }\end{array}$ & $\begin{array}{l}\text { Contraindicated by Stevens- } \\
\text { Johnson syndrome or toxic } \\
\text { epidermal necrolysis with HLA- } \\
B^{*} 1502 \text {. Multiple drug interactions } \\
\text { involving hepatic enzymes. } \\
\text { Common side effects include } \\
\text { nystagmus, dizziness, diplopia, } \\
\text { lightheadedness, and lethargy. Rare } \\
\text { side effects include aplastic anemia } \\
\text { and agranulocytosis }\end{array}$ \\
\hline & Gabapentin & PO & N/A & $5-7 \mathrm{~h}$ & $\begin{array}{l}\text { Common side effects include } \\
\text { sedation, confusion, dizziness, and } \\
\text { ataxia. Adjust dosing in renal failure } \\
\text { patients }\end{array}$ \\
\hline
\end{tabular}

Abbreviations: intravenous (IV), intramuscular (IM), PO (oral), PR (rectal) Adapted from Barr et al (2013) 


\section{CONCLUSION}

Pain among patients admitted to the ICU is common, and must be treated appropriately to avoid long-term complications. Frequent and objective reassessment of patients' pain is the basis of appropriate care. Opioid therapy remains the standard of care in most cases, but non-opioid and non-pharmacological interventions may have some utility in selected cases. Patients who are discharged from the ICU should be referred to appropriate follow-up care, including ongoing pain management. In the long term, ongoing pain or traumatic memories associated with pain experienced during illness represent a significant burden on many patients, further emphasizing the importance of managing pain in all critically ill patients.

\section{REFERENCES}

1. Barr J, Fraser GL, Puntillo K, et al. Clinical practice guidelines for the management of pain, agitation, and delirium in adult patients in the intensive care unit. Crit Care Med. 2013;41:263-306.

2. Chang H-Y, Daubresse M, Kruszewski SP, et al. Prevalence and treatment of pain in EDs in the United States, 2000 to 2010. Am J Emerg Med. 2014 May;32(5):421-31.

3. Schelling G, Richter M, Roozendaal B, et al. Exposure to high stress in the intensive care unit may have negative effects on health-related quality-of-life outcomes after cardiac surgery. Crit Care Med. 2003 Jul;31(7):1971-80.

4. Granja C, Gomes E, Amaro A, et al. Understanding posttraumatic stress disorder-related symptoms after critical care: the early illness amnesia hypothesis. Crit Care Med. 2008 Oct;36(10):2801-9.

5. Akca O, Melischek M, Scheck T, et al. Postoperative pain and subcutaneous oxygen tension. Lancet. 1999 Jul 3;354(9172):41-2.

6. Pollock RE, Lotzova E, Stanford SD. Mechanism of surgical stress impairment of human perioperative natural killer cell cytotoxicity. Arch Surg. 1991 Mar;126(3):338-42.

7. Peterson PK, Chao CC, Molitor T, et al. Stress and pathogenesis of infectious disease. Rev Infect Dis. 1991;13(4):710-20.

8. Miner JR, Burton JH. Pain management. In: Walls RM, Hockberger RS, Gausche-Hill M, editors. Rosen's Emergency Medicine. Ninth Ed. Elsevier; 2018. p. 34-51.

9. Shannon K, Bucknall T. Pain assessment in critical care: what have we learnt from research. Intensive Crit Care Nurs. 2003 Jun;19(3):154-62.

10. International Association for the Study of Pain. IASP taxonomy. [Internet]. [cited 2017 Nov 18]. Available from: http://www. iasp-pain.org/AM/Template.cfm?Section=Pain_Defi...\%0Aisplay. cfm\&ContentID=1728\#Pain.

11. Chanques G, Viel E, Constantin J-M, et al. The measurement of pain in intensive care unit: comparison of 5 self-report intensity scales. Pain. 2010 Dec;151(3):711-21.

12. Gelinas $\mathrm{C}$, Arbour $\mathrm{C}$, Michaud $\mathrm{C}$, et al. Implementation of the criticalcare pain observation tool on pain assessment/management nursing practices in an intensive care unit with nonverbal critically ill adults: a before and after study. Int J Nurs Stud. 2011 Dec;48(12):1495-504.

13. Gelinas C, Arbour C, Michaud C, et al. Patients and ICU nurses' perspectives of non-pharmacological interventions for pain management. Nurs Crit Care. 2013 Nov;18(6):307-18.

14. Timmers TK, Verhofstad MH, Moons KG, et al. Long-term quality of life after surgical intensive care admission. Arch Surg. 2011 Apr;146(4):412-8.
15. Hrvatin V. Program aims to help people RECOVER from the ICU. The Toronto Star [Internet]. Toronto, ON; 2017 Oct 23; Available from: https://www.thestar.com/life/health_wellness/news_ research/2017/10/23/program-aims-to-help-people-recover-from-theicu.html

16. Yaffe PB, Green RS, Butler MB, et al. Is admission to the intensive care unit associated with chronic opioid use? A 4-year followup of intensive care unit survivors. J Intensive Care Med. 2017 Aug;32(7):429-35.

17. Busse J, ed. The 2017 Canadian guideline for opioids for chronic noncancer pain [Internet]. Hamilton (ON): National Pain Centre; 2017. 105 p. Available from: http://www.cfpc.ca/chronic-non-cancer-painmanagement-opioid-resources 